\title{
Analisis Automorfisma Graf Pembagi-nol dari Ring Komutatif dengan Elemen Satuan
}

\author{
Kurniawan Sugiarto ${ }^{a, *}$, Mamika Ujianita Romdhini ${ }^{b}$, Ni Wayan Switraynic \\ ${ }^{a}$ Universitas Mataram, Jl.Majapahit 62, Mataram, 83125, Indonesia,. Email: kurniawansugiarto05@gmail.com \\ ${ }^{b}$ Universitas Mataram, Jl.Majapahit 62, Mataram,83125, Indonesia,.Email: mamika_ur@yahoo.com \\ ${ }^{c}$ Universitas Mataram, Jl.Majapahit 62, Mataram,83125, Indonesia,.Email:niwayan.switrayni@unram.ac.id
}

\section{ABSTRACT}

Zero-divisor graphs of a commutative ring with identity has 3 specific simple forms, namely star zero-divisor graph, complete zero-divisor graph and complete bipartite zero-divisor graph. Graph automorphism is one of the interesting concepts in graph theory. Automorphism of graph $\mathrm{G}$ is an isomorphism from graph $\mathrm{G}$ to itself. In other words, an automorphism of a graph $\mathrm{G}$ is a permutation $\varphi$ of the set points $V(G)$ which has the property that $(x, y) \in E(G)$ if and only if $(\varphi(x), \varphi(y)) \in E(G)$, i.e. $\varphi$ preserves adjacency.This study aims to analyze the form of zero-divisor graph automorphisms of a commutative ring with identity formed. The method used in this study was taking sampel of each zero-divisor graph to represent each graph. Thus, pattern and shape of automorphism of each graph can be determined. Based on the results of this study, a star zero-divisor graph with pattern $K_{1 .(p-1)}$, where $p$ is prime, has $(p-1)$ ! automorphisms, a complete zero-divisor graph with pattern $K_{(p-1)}$, where $p$ is prime, has $(p-1)$ ! automorphisms, and a complete bipartite zero-divisor graph with pattern $K_{(p-1),(q-1)}$, where $p$ is prime, has $(p-1) ! *(q-1)$ !automorphisms, when $p \neq q$ and $2[(p-1) ! *(p-1) !]$ automorphisms when $p=q$.

Keywords: Ring, Graph Automorphism, star zero-divisor graph, Complete zero-divisor graph, Complete bipartite zero-divisor graph

\section{PENDAHULUAN}

Salah satu konsep yang menarik dari Ring adalah himpunan pembagi-nol. Suatu Ring $R$ dikatakan memuat pembagi-nol jika terdapat $x, y \in R$ dimana $x, y \neq 0$ sedemikian sehingga $x . y=0$.Himpunan pembagi-noldari sebuah ring dinotasikan dengan $Z(R)$ dapat direpresentasikan ke dalam bentuk graf

Graf pembagi-nol pada ring komutatif yang dinotasikan dengan $\Gamma(R)$ adalah suatu graf sederhana dengan simpulsimpulnya adalah semua elemen dari himpunan pembagi nol yang tak nol dari Ring $R$. Pada graf pembagi nol dari Ring Komutatif, simpul $x$ dan $y$ dikatakan terhubung jika dan hanya jika $x, y=0$ dengan $x, y \in Z(R)^{*}$, dimana $Z(R)^{*}=Z(R)-\{0\}$.
Wicaksono (2013), dalam tulisanya menulis tentang sifat-sifat graf pembagi nol dari ring komutatif dengan elemen satuan. Hasil dari penelitianya hanya berupa konstruksi graf dari himpunan pembagi nol pada ring komutatif dengan elemen satuan. Graf-graf yang terbentuk berupa graf pembagi-nol bintang, graf pembagi-nol lengkap dan graf pembagi-nol bipartit lengkap.

Hal inilah yang kemudian menarik untuk dilakukan penelitian, yaitu untuk mengetahui bagaimana bentuk automorfisma dari graf-graf pembagi nol dari ring komutatif dengan elemen satuan yang terbentuk?Apakah ada perbedaan automorfisma graf yang dibentuk dengan automorfisma graf pada umumnya? 


\section{TINJAUN PUSTAKA}

\subsection{Graf pembagi-nol bintang}

Graf bintang memiliki ciri utama yaitu memiliki sebuah simpul pusat.Berikut ini, diberikan sebuah teorema yang menunjukkan bentuk ring yang menghasilkan graf yang mempunyai suatu simpul yang terhubung dengan setiap simpul lainnya.

Teorema 1 (Wicaksono, 2013) Diberikan R ring komutatif dengan elemen satuan. Graf $\Gamma(\mathrm{R})$ memiliki suatu simpul yang terhubung dengan setiap simpul lainnya jika dan hanya jika $\mathrm{R} \cong \mathbb{Z}_{2} \times \mathrm{A}$, dimana $\mathrm{A}$ adalah daerah integral, atau $\mathrm{Z}(\mathrm{R})$ adalah ideal penghilang.

\section{Bukti:}

$(\Longrightarrow$ ) Misalkan $Z(R)$ bukan merupakan ideal penghilang dan $\operatorname{ann}(a)=I$ dengan $a \in Z(R)$, dimana $a \neq 0$ terhubung ke setiap simpul lainnya. Andaikan $a \in I$, karena simpul aterhubung ke setiap simpul lainnya maka $Z(R)=I$. Hal ini kontradiksi dengan $Z(R)$ bukan ideal penghilang.Akibatnya $I$ merupakan ideal penghilang yang maksimal, sehingga berdasarkan Proposisi 2.1, ideal $I$ merupakan ideal prima. Selanjutnya, karena $a \in Z(R)$ maka terdapat $b \neq 0 \in Z(R)$ sehingga $a b=0$ atau $a^{2} b=$ $(a a) b=a(a b)=a 0=0$, diperoleh $\quad a^{2} \in Z(R)$. Andaikan $a^{2}=0$ maka $a a=0$ mengakibatkan $a \in \operatorname{ann}(a)=I$. Hal ini, kontradiksi dengan $a \notin \operatorname{ann}(a)=I$. Jadi, haruslah $a^{2} \neq 0$ sehingga $a^{2} \in V(\Gamma(R))$. Jika $a^{2} \neq$ amaka $a^{3}=a^{2} a=0$, sehingga $a^{2} \in I$. Akibatnya, karena $I$ ideal prima, diperoleh $a \in I$. Hal ini kontradiksi dengan $a \notin \operatorname{ann}(a)=I$. Oleh karena itu, haruslah $a^{2}=a$. Artinya, $a$ adalah unsur idempoten di $R$. Akibatnya, $R \quad$ dapatdidekomposisi menjadi $R=R a \oplus R(1-a)$. Oleh karena itu, dapat ditulis bahwa $R \cong R_{1} \times R_{2}$ dengan $(1,0)$ adalah salah satu simpul yang terhubung dengan setiap simpul yang lainnya. Dapat dilihat bahwa, untuk sebarang $c \in R_{1}-\{0,1\}$ merupakan pembagi-nol di $R$. Akibatnya, $\quad(c, 0)=(c, 0)(1,0)=0, \quad$ sehingga $c=0$. Hal ini, kontradiksi dengan $(c, 0)$ sebagai pembagi-nol di $R$, artinya bahwa $(1,0)$ adalah satusatunya simpul yang terhubung dengan setiap simpul yang lain, sehingga $R_{1} \cong \mathbb{Z}_{2}$. Selanjutnya, andaikan $R_{2}$ bukan merupakan daerah integral, maka tedapat $a, b \neq 0 \in Z\left(R_{2}\right)$, sehingga $(0, a)(1, b)=0$. Akan tetapi, terdapat sebuah simpul yang tak terhubung ke simpul pusat $(1,0)$, yaitu $(1,0)(1, a) \neq 0$. Hal ini kontradiksi dengan simpul $(1,0)$ yang terhubung ke setiap simpul lainnya, maka haruslah $R_{2}$ merupakan suatu daerah integral.

$(\Longleftarrow)$ Misalkan $R \cong Z_{2} \times A$ dengan $A$ adalah daerah integral. Ambilsebarang $a \neq 0 \in A$, sehingga $(1,0)(0, a)=0$. Terlihat bahwa terdapat suatu simpul yang terhubung dengan setiap simpul lainnya, yaitu $(1,0)$. Misalkan $Z(R)$ adalah suatu ideal penghilang, maka terdapat $a \neq 0 \in$ $R$ sehinggaann $(a)=Z(R)$. Akibatnya, $a \cdot b=$ $0 \forall b \in Z(R)-\{0, a\}$. Jadi, $\Gamma(R)$ memiliki simpul pusat yang terhubung ke setiap simpul lainnya.

Bukti dari Teorema 1, menjelaskan bahwa jika di dalam suatu graf pembagi-nol $\Gamma(R)$ terdapat suatu simpul $x$ yang terhubung dengan setiap simpul lainnya, maka $x$ merupakan elemen idempoten dengan $R x=\{0, x\}$ merupakan suatu ideal prima dari $R$ atau $Z(R)$ adalah suatu ideal penghilang. Berdasarkan Teorema 1, didapatkan sebuah akibat dan lemma sebagai berikut:

Akibat 1 (Livingstone, 1999) Diberikan $R$ ring komutatif berhingga. Terdapat suatu simpul dalam $\Gamma(R)$ yang terhubung dengan setiap simpul lainnya jika dan hanya jika $R \cong \mathbb{Z}_{2} \times F$, dimana $F$ adalah lapangan berhingga atau $R$ adalah ring lokal. Lebih lanjut, $|\Gamma(R)|=|F|=p^{n}$ jika $R \cong Z_{2} \times F$ dan $|\Gamma(R)|=p^{n}-1$ jika $R$ ring lokal.

Akibat 1 di atas, menjelaskan bahwa $\Gamma(R)$ memiliki simpul yang terhubung ke setiap simpul lainnya jika $R \cong \mathbb{Z}_{2} \times F$ dengan $F$ adalah lapangan berhingga, atau $R$ adalah ring lokal. Adanya simpul yang terhubung ke setiap simpul lainnya memungkinkan $\Gamma(R)$ memiliki lebih dari satu simpul yang terhubung ke setiap simpul lainnya.Hal ini jelas tidak sesuai dengan definisi dari graf pembagi-nol bintang yang hanya memiliki satu simpul yang terhubung ke setiap simpul lainnya. Berikut ini, akan diberikan sebuah lemma yang menjelaskan bahwa $\Gamma(R)$ memiliki tepat satu simpul yang terhubung ke setiap simpul lainnya (simpul pusat).

Lemma 1 (Livingstone, 1999) Diberikan $R$ ring komutatif berhingga. Jika $\Gamma(R)$ memiliki tepat satu simpul yang terhubung dengan setiap simpul lainnya dan tidak ada lagi simpul lain yang berhubungan maka $R \cong \mathbb{Z}_{2} \times F$, dimana $F$ adalah lapangan berhingga dengan $|F| \geq 3$, atau $R$ adalah ring lokal dengan ideal maksimal $M$ yang memenuhi $R / M \cong \mathbb{Z}_{2}, M^{3}=0$, dan $\left|M^{2}\right| \leq 2$, sehingga $|\Gamma(R)|$ adalah $p^{n}$ atau $2^{n}-1$, untuk bilangan prima $p$ dan bilangan bulat positif $n \geq 1$.

Bukti: 
Misalkan $R$ ring komutatif berhingga dan $\Gamma(R)$ memiliki tepat satu simpul yang terhubung dengan setiap simpul lainnya, namakan $x$. Misalkan $R \nsubseteq \mathbb{Z}_{2} \times F$, maka menurut Akibat $1, R$ adalah ring lokal. Misalkan, $M$ adalah ideal maksimal pada $R$, karena $x \in Z(R)$ maka $x \in M$. Disisi lain, karena $R$ berhingga maka $M=\operatorname{ann}(y)$ untuk suatu $y \in M$. Selanjutnya, karena $\Gamma(R)$ memilki tepat satu simpul yang terhubung dengan setiap simpul lainnya yaitu $x$, maka haruslah $y=x$, sehingga diperoleh $M=\operatorname{ann}(x)$. Misalkan $k$ adalah bilangan bulat terkecil sehingga $M^{k}=$ 0, maka $M=\operatorname{ann}(z)$ untuk sebarang $z \in M^{k-1}$. Akibatnya, $M^{k-1}=\{0, x\}$, diperoleh $\left|M^{k-1} / M^{k}\right|=2$, mengakibatkan $R / M \cong Z_{2}$. Andaikan $k \geq 4$, maka $\left|M^{k-2}\right| \geq 4$. Akibatnya untuk sebarang $a, b \in M^{k-2}-$ $M^{k-1}$ yang berbeda maka $a b \in M^{2 k-4} \subset M^{k}=0$. Diperoleh $a b=0$, artinya $a$ terhubung dengan $b$. Kontradiksi, jadi haruslah $k \leq 3$. Perhatikan bahwa:

Jika $k=3$, maka $M^{3}=0$, sehingga $\left|M^{2}\right|=2$.

Jika $k=2$, maka $M^{2}=0$, sehingga $\left|M^{2}\right|=1$.

Jika $k=1$, maka $M=0$, sehingga $\left|M^{2}\right|=1$.

Sehingga, untuk $k \leq 3$ maka $\left|M^{2}\right| \leq 2$. Selanjutnya, menurut Akibat 1 , jika $R \cong Z_{2} \times F$ maka $|\Gamma(R)|=p^{n}$ dan jika $R$ adalah ring lokal maka $|\Gamma(R)|=p^{n}-1$, untuk suatu bilangan bulat $n \geq 1$ dan $p$ bilangan prima. Selanjutnya,karena $\left|M^{2}\right| \leq 2$, maka haruslah $|\Gamma(R)|=$ $2^{n}-1$.

Teoremal dan Lemma 1 menjelaskan bahwa bentuk ring yang menghasilkan graf dengan simpul yang terhubung dengan simpul yang lainnya, atau bisa dikatakan sebagai simpul pusat. Adanya simpul pusat memang merupakan salah satu ciri dari graf bintang, akan tetapi ada satu ciri yang tidak boleh dilupakan, yaitu tidak adanya keterhubungan dalam graf tersebut selain dengan simpul pusat. Berikut ini akan diberikan teorema yang membuktikan bahwa graf pembagi-nol bintang hanya dapat terbentuk jika ring $R \cong \mathbb{Z}_{2} \times F$, dimana $F$ adalah lapangan berhingga.

Teorema 2 (Wicaksono, 2013) Diberikan $R$ adalah ring komutatif berhingga dengan elemen satuan dengan $|\Gamma(R)| \geq 4$. Graf $\Gamma(R)$ adalah graf bintang jika dan hanya jika $R \cong \mathbb{Z}_{2} \times F$, dimana $F$ adalah lapangan berhingga.

\section{Bukti:}

$\left(\Longrightarrow\right.$ )Andaikan $R ¥ \mathbb{Z}_{2} \times F$, dimana $\mathrm{F}$ adalah lapangan berhingga, maka berdasarkan Akibat 1 dan Lemma 1 , haruslah $R$ ring lokal dengan $|M|=2^{k}$, dengan $k \geq 3, \quad$ karena $|\Gamma(R)| \geq 4$ dan $\left|M^{2}\right|=2$. Selanjutnya, karena $\Gamma(R)$ graf bintang dan $R$ adalah ring lokal yang berhingga, maka $Z(R)=M=$ ann $(x)$, dimana $x$ adalah simpul yang terhubung dengan setiap simpul lainnya. Pilih $a, b, c, d \in M^{*}-$ $\{x\}$ yang berbeda maka $a b=a c=a d \in M^{2}$. Selanjutnya, karena $\Gamma(R)$ adalah graf bintang maka $a b=a c=a d=x . \quad$ Diperoleh, $\quad a(b-c)=$ $a(b-d)=0$.Akibatnya, $b-c, b-d \in \operatorname{ann}(a)=$ $\{0, x\}$, sehingga $b \neq c$ dan $b \neq d$, maka $b-c \neq 0$ dan $b-d \neq 0$. Akibatnya, $b-c=x=b-d$, sehingga diperoleh $c=d$. Kontradiksi dengan $c$ dan $d$ berbeda. Jadi, haruslah $R \cong \mathbb{Z}_{2} \times F$, dimana $F$ lapangan berhingga.

$(\Leftarrow)$ Diketahui $R \cong \mathbb{Z}_{2} \times F$, dimana $F$ adalah lapangan berhingga. Berdasarkan Lemma $1, \Gamma(R)$ memiliki tepat satu simpul yang terhubung dengan setiap simpul lainnya, yaitu $(1,0)(0, a)=0, \forall a \in F, a \neq$ 0 . Selanjutnya, karena $F$ adalah lapangan berhingga, maka tidak ada yang menyebabkan keterhubungan diantara setiap simpul pada $\Gamma(R)$,kecuali dengan simpul pusat. Dengan kata lain, $\Gamma(R)$ adalah graf bintang.

Contoh 1:

Misalkan $R \cong \mathbb{Z}_{2} \times \mathbb{Z}_{7}$, maka $\Gamma(R)$ adalah graf pembaginol bintang.

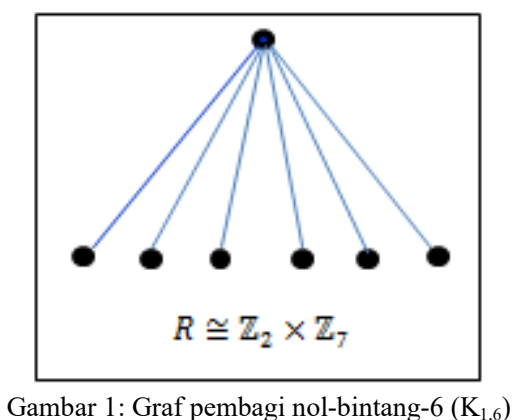

\subsection{GrafPembagi-nol Lengkap}

Suatu graf dikatakan lengkap jika setiap simpulnya terhubung dengan setiap simpul yang lain, maka $\Gamma(R)$ adalah graf lengkap jika $x . y=0, \forall x, y \in Z(R)$, dengan kata lain setiap anggota dari pembagi-nol $Z(R)$ selalu terhubung dengan diameter satu. Berikut ini, diberikan teorema yang menjelaskan tentang graf pembagi-nol lengkap.

Teorema 3 (Livingstone, 1999) Diberikan ring komutatif $R$. Graf $\Gamma(R)$ adalah graf lengkap jika dan hanya jika $R \cong \mathbb{Z}_{2} \times \mathbb{Z}_{2}$ atau $x . y=0, \forall x, y \in Z(R)$.

Bukti:

$(\Longrightarrow)$ Misalkan $\quad \Gamma(R)$ adalah graf lengkap. Akan 
ditunjukkan $\quad R \cong \mathbb{Z}_{2} \times \mathbb{Z}_{2}$, terdapat $\quad x \in Z(R)$ dengan $x^{2} \neq 0$. Andaikan $x^{2} \neq x$, maka $x^{3}=$ $x^{2} \cdot x=0$. Akibatnya, $x^{2}\left(x+x^{2}\right)=x^{3}+x^{3} x=$ 0 , karena $x^{2} \neq 0$, maka $x+x^{2} \in Z(R)$. Jika $x+x^{2}=x$, maka $x^{2}=0$. Hal ini kontradiksi dengan yang dimisalkan, yaitu $x^{2} \neq 0$. Diperoleh $x+x^{2} \neq x$, maka $x^{2}=x^{2}+x^{3}=x\left(x+x^{2}\right)=$ 0 , dikarenakan graf $\Gamma(R)$ merupakan graf lengkap. Hal ini kontradiksi dengan $x^{2} \neq 0$. Jadi, haruslah $x^{2}=x$. Selanjutnya, karena $x^{2}=x$ maka menurut bukti Teorema 1 berlaku $R \cong \mathbb{Z}_{2} \times A$, dimana $A$ adalah daerah integral, sehingga $R \cong \mathbb{Z}_{2} \times \mathbb{Z}_{2}$, karena $\mathbb{Z}_{2}$ merupakan satu-satunya daerah integral yang dapat memenuhi graf $\Gamma(R)$ menjadi graf lengkap.

$(\Leftarrow)$ Berdasarkan definisi jelas bahwa jika $x . y=0$, $\forall x, y \in Z(R)$ maka graf $\Gamma(R) \quad$ berupa graf lengkap. Misalkan $R \cong \mathbb{Z}_{2} \times \mathbb{Z}_{2}$, maka $Z(R)=$ $\{(0,1),(1,0)\}$. Artinya bahwa, simpul $(0,1)$ terhubung dengan simpul $(1,0)$, maka menurut definisi $\Gamma(R)$ merupakan graf lengkap.

Teorema3 di atas menjelaskan bahwa setiap elemen pada graf pembagi-nol lengkap berupa elemen nilpoten, tepatnya jika $\Gamma(R)$ merupakan graf lengkap maka untuk setiap $x \in Z(R)$ berlaku $x^{2}=0$. Akan tetapi, jika $R \nsubseteq \mathbb{Z}_{2} \times$ $\mathbb{Z}_{2}$ maka $R$ akan berupa ring lokal. Hal ini, dijelaskan dalam teorema berikut ini:

Teorema 4 (Wicaksono 2013) Diberikan $R$ adalah ring komutatif berhingga. Jika $\Gamma(R)$ merupakan graf lengkap maka $R \cong Z_{2} \times Z_{2}$ atau $R$ adalah ring lokal dengan char $R=p$ atau $p^{2}$ dan $|\Gamma(R)|=p^{n}-1$ untuk bilangan prima $p$ dan bilangan bulat $n \geq 1$.

\section{Bukti:}

Misalkan $R$ adalah ring komutatif berhingga dan $\Gamma(R)$ merupakan graf lengkap. Menurut Teorema 3, $\Gamma(R)$ merupakan graf lengkap jika dan hanya jika $R \cong \mathbb{Z}_{2} \times \mathbb{Z}_{2}$. Misalkan $R ¥ \mathbb{Z}_{2} \times \mathbb{Z}_{2}$, berdasarkan Akibat 1 $R$ adalah ring lokal dengan ideal maksimal $M$. Oleh karena itu, $\operatorname{char} R=p^{m}, m \geq 1$. Jika $m \geq 3$, maka terdapat pembagi-nol yang tidak terhubung dengan suatu pembaginol yang lainnya dalam $R$. Oleh karena itu, $\operatorname{char} R=p^{m}$ untuk $m=1$ dan 2. Selanjutnya, karena $M$ adalah $p$-grup dan $R$ ring lokal berhingga maka $|M|=p^{n}$ untuk suatu bilangan bulat $n \geq 1$ dan $Z(R)=M$. Diperoleh, $|Z(R)|=$ $p^{n}$, akibatnya $|\Gamma(R)|=p^{n}-1$, karena elemen 0 bukan simpul pada $\Gamma(R)$.
Contoh 2:

Misalkan $R \cong \mathbb{Z}_{25}$, maka $R$ adalah ring lokal dengan $\operatorname{char}(R)$. Akibatnya, $\Gamma(R)$ adalah graf pembagi-nol lengkap

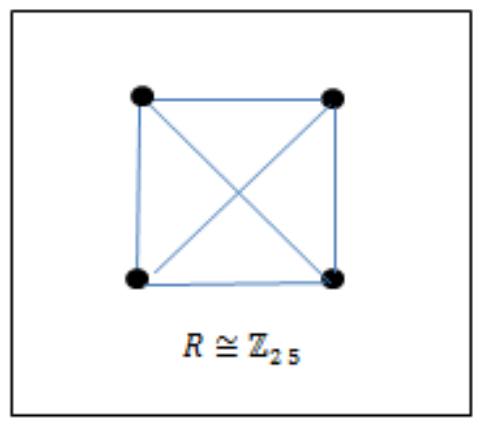

Gambar.2: Graf pembagi-nol lengkap $K_{4}$

\subsection{GrafPembagi-nol Bipartit Lengkap}

Misalkan $R \cong R_{1} \times R_{2}$, graf $\Gamma(R)$ akan berupa graf bipartit lengkap dengan $R_{1}, R_{2}$ adalah suatu daerah integral. Misalkan $R_{2}$ bukan merupakan daerah integral, artinya terdapat $x, y \in R_{2}$ dengan $x . y=0$, maka akan ada keterhubungan dalam partisi yang sama, yaitu $(0, x)$ dengan $(0, y)$. Selain itu, dengan adanya pembagi-nol dalam suatu partisi akan memicu munculnya simpul-simpul lain yang membuat definisi graf lengkap bipartit tidak akan pernah terpenuhi, seperti $(1, y),(2, y), \ldots,(m, y)$, keseluruhan simpul tersebut akan terhubung ke $(0, x)$, begitu pula dengan $(1, x),(2, x), \ldots,(m, x)$ adalah simpulsimpul yang akan terhubung dengan simpul $(0, y)$. Sehingga didapatkan sebuah akibat yang menjelaskan eksistensi dari graf bipartit lengkap sebagai berikut:

Akibat 2 (Wicaksono, 2013) Diberikan $R$ ring komutatif berhingga. Graf $\Gamma(R)$ adalah graf bipartit lengkap dengan $|\Gamma(R)|=m+n-2$ jika dan hanya jika $R \cong \mathbb{Z}_{m} \times \mathbb{Z}_{n}$, dimana $m, n \in P, P$ adalah himpunan bilangan prima.

\section{Bukti:}

$(\Longrightarrow)$ Misalkan $R$ adalah ring komutatif berhingga dengan elemen satuan. Selanjutnya, karena graf $\Gamma(R)$ merupakan graf bipartit lengkap, maka graf $\Gamma(R)$ dapat dipartisi menjadi 2 himpunan simpul yang berbeda. Akibatnya, $R \cong R_{1} \times R_{2}$. Untuk suatu $R_{1}$ dan $R_{2}$ daerah integral. Selanjutnya, karena $|\Gamma(R)|=m+n-2$, maka $\left|R_{1}\right|=m$ dan $\left|R_{2}\right|=$ $n$. Definisikan homomorfisma ring $\varphi: \mathbb{Z} \rightarrow R_{1}$, maka $\operatorname{ker}(\varphi)=k \mathbb{Z}$ dengan $k=\operatorname{char}(R)$, dimana $k$ adalah suatu bilangan prima. Selanjutnya, karena $\left|R_{1}\right|=m$, dengan $m$ suatu bilangan prima, maka $m=k$. Akibatnya, $\mathbb{Z}_{m} \cong \mathbb{Z} / m \mathbb{Z} \cong \varphi(\mathbb{Z})$. Selain itu, 
karena $\varphi(\mathbb{Z})$ subring dari $R_{1}$ dan $|\varphi(\mathbb{Z})|=m=$ $\left|R_{1}\right|, \quad$ maka $\varphi(\mathbb{Z})=R_{1}$. Diperoleh, $\mathbb{Z}_{m} \cong R_{1}$. Dengan cara yang sama, didefinisikan $\varphi: \mathbb{Z} \rightarrow R_{2}$ adalah suatu homomorfisma ring dari $\mathbb{Z} k e R_{2}$, maka $\operatorname{ker}(\varphi)=k \mathbb{Z}$ dengan $k=\operatorname{char}(R)$, dimana $k$ adalah suatu bilangan prima. Selanjutnya, karena $\left|R_{2}\right|=n$, dengan $n$ suatu bilangan prima maka $n=k$. Akibatnya, $\mathbb{Z}_{n} \cong \mathbb{Z} / n \mathbb{Z} \cong \varphi(\mathbb{Z})$. Selain itu, karena $\varphi(\mathbb{Z})$ subring dari $R_{2}$ dan $|\varphi(\mathbb{Z})|=n=\left|R_{2}\right|$, maka $\varphi(\mathbb{Z})=R_{2}$. Diperoleh, $\mathbb{Z}_{n} \cong R_{2}$. Dengan demikian diperoleh, $R \cong \mathrm{Z}_{\mathrm{m}} \times \mathrm{Z}_{\mathrm{n}}$, dimana $\mathrm{m}, \mathrm{n} \in \mathrm{P}$, $P$ adalah himpunan bilangan prima.

$(\Leftarrow)$ Misalkan $R \cong \mathbb{Z}_{\mathrm{m}} \times \mathbb{Z}_{\mathrm{n}}$, dimana $m, n \in P$, dimana $P$ adalah himpunan bilangan prima, maka dapat ditulis $R \cong R_{1} \times R_{2}$, dengan $R_{1} \cong \mathbb{Z}_{m}$ dan $R \cong \mathbb{Z}_{2}$. Misalkan $V_{1}=\left\{\left(x_{i}, 0\right) \mid 0 \neq x_{i} \in R_{1}: i=\right.$ $\left.1,2, \ldots . m, 0 \in R_{2}\right\} \quad$ dan $\quad V_{2}=\left\{\left(0, y_{j}\right) \mid 0 \in\right.$ $\left.R_{1}, 0 \neq y_{j} \in R_{2}: j=1,2, \ldots . n\right\}$ merupakan partisi pada graf $\Gamma(R)$, maka $V_{1} \cup V_{2}=Z(R)^{*}=$ $V(\Gamma(R))$. Jika diambil $a \in V_{1}$ dan $b \in V_{2}$ sebarang maka $a \cdot b=0$. Artinya bahwa, setiap simpul yang ada pada $V_{1}$ terhubung dengan semua simpul yang ada pada $V_{2}$. Selanjutnya, karena $m$ dan $n$ prima maka $\mathbb{Z}_{\mathrm{m}}$ dan $\mathrm{Z}_{\mathrm{n}}$ adalah daerah intgral, sehingga $R_{1}$ dan $R_{2}$ daerah integral. Akibatnya, tidak terdapat keterhubungan pada simpul-simpul pada partisi yang sama. Akibatnya, graf merupakan graf bipartit lengkap.

Contoh 3:

Misalkan $R \cong \mathbb{Z}_{3} \times \mathbb{Z}_{5}$, maka $\Gamma(R)$ adalah graf pembaginol bipartit lengkap.

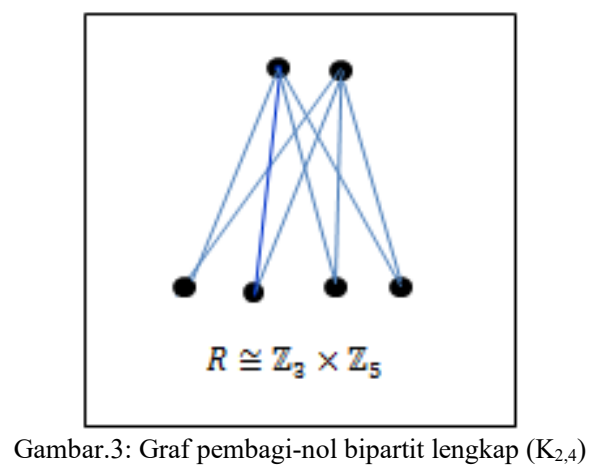

\section{PEMBAHASAN}

Automorfisma dari graf $G$ adalah suatu isomorfisma dari graf $G$ ke dirinya sendiri. Dengan kata lain, automorfisma dari graf $G$ merupakan suatu permutasi $\varphi$ dari himpunan $\mathrm{V}(G)$ yaitu himpunan semua titik-titik dari $G$, yang bersifat $(x, y) \in E(G)$ jika dan hanya jika $(\varphi(x), \varphi(y)) \in E(G)$, yaitu $\varphi$ mengawetkan ketetanggan pada $G$.

\subsection{Identifikasi Graf Pembagi-nol}

Ada 3 macam jenis graf sederhana khusus yang terbentuk dari graf pembagi-nol pada ring komutatif dengan eleman satuan, yaitu graf pembagi-nol bintang, graf pembagi-nol lengkap dan graf pembagi-nol bipartit lengkap. Graf pembagi-nol $\Gamma(R)$ bintang akan terbentuk jika $R \cong \mathbb{Z}_{2} \times F$, dimana $F$ merupakan lapangan berhingga. Graf pembagi-nol $\Gamma(R)$ lengkap akan terbentuk apabila $R \cong \mathbb{Z}_{2} \times \mathbb{Z}_{2}$ atau $R$ adalah ring lokal dengan char $=p$ atau $p^{2}$, sedangkan graf pembagi-nol bipartit lengkap akan terbentuk jika dan hanya jika $R \cong \mathbb{Z}_{m} \times \mathbb{Z}_{n}$, dimana $m, n \in P, P$ adalah himpunan bilangan prima

\section{Graf pembagi-nol bintang}

Berdasarkan Teorema 1 dan Torema 2, graf pembaginol bintang dari suatu ring komutatif berhingga dengan elemen satuan jika akan terbentuk jika $R \cong \mathbb{Z}_{2} \times F, \quad$ dengan $\quad F \quad$ lapangan berhinggadimana $|\Gamma(R)| \geq 4$ dan $R \cong \mathbb{Z}_{2} \times \mathbb{Z}_{p}$, dengan $p$ adalah himpunan bilangan prima, dimana $p \geq 5$.

Contoh4:

Graf pembagi-nol bintang dengan $R \cong \mathbb{Z}_{2} \times \mathbb{Z}_{5}$

$$
\begin{gathered}
\mathbb{Z}_{2} \times \mathbb{Z}_{5}=\{0,1\} \times\{0,1,2,3,4\} \\
=\{(0,0),(0,1),(0,2),(0,3),(0,4),(1,0), \\
(1,1),(1,2),(1,3),(1,4)\}
\end{gathered}
$$

Maka, pembagi-nol dari $R \cong \mathbb{Z}_{2} \times \mathbb{Z}_{5}$ adalah:

Sehingga, diperoleh:

$$
\begin{aligned}
& (1,0) \cdot(0,1)=0 \\
& (1,0) \cdot(0,2)=0 \\
& (1,0) \cdot(0,3)=0 \\
& (1,0) \cdot(0,4)=0
\end{aligned}
$$

$Z(R)=\{(0,0),(1,0),(0,1),(0,2),(0,3),(0,4)\}$

Bentuk graf $\Gamma(R)$ dengan $R \cong \mathbb{Z}_{2} \times \mathbb{Z}_{5}$ dapat dilihat pada Gambar4 berikut:

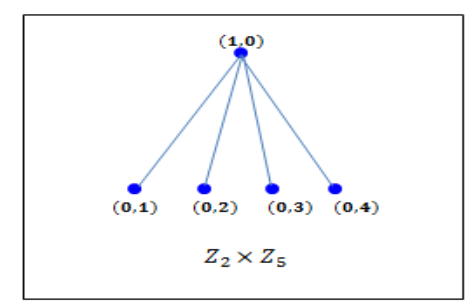


Gambar.4: Graf pembagi-nol bintang $K_{1,4}$

Berdasarkan Gambar4, terlihat bahwa pola dari $\Gamma(R)$ bintang dengan $R \cong \mathbb{Z}_{2} \times \mathbb{Z}_{5}$ adalah $K_{(2-1),(5-1)}=K_{1,4}$, dan $|\Gamma(R)|=(5-1)+1=5$.

Sehingga, untuk graf pembagi-nol bintang yang lain didapatkan:

Tabel.1: Pola Graf Pembagi-nol Bintang

\begin{tabular}{cccc}
\hline No & $\begin{array}{c}\text { Bentuk } \\
\text { Ring }\end{array}$ & $\begin{array}{c}\text { Derajat } \\
\text { Graf } \Gamma(R)\end{array}$ & Pola Graf $\Gamma(R)$ \\
\hline 1 & $\mathbb{Z}_{2} \times \mathbb{Z}_{5}$ & $(5-1)+1=5$ & $K_{(2-1),(5-1)}=K_{1,4}$ \\
\hline 2 & $\mathbb{Z}_{2} \times \mathbb{Z}_{7}$ & $(7-1)+1=7$ & $K_{(2-1),(7-1)}=K_{1,6}$ \\
\hline 3 & $\mathbb{Z}_{2} \times \mathbb{Z}_{11}(11-1)+1=11$ & $K_{(2-1),(11-1)}=K_{1,10}$ \\
\hline 4 & $\mathbb{Z}_{2} \times \mathbb{Z}_{13}$ & $(13-1)+1=13$ & $K_{(2-1),(13-1)}=K_{1,12}$ \\
\hline
\end{tabular}

\section{Graf pembagi-nol lengkap}

Berdasarkan Teorema 4, jika graf pembagi-nol lengkap terbentuk, maka $R \cong \mathbb{Z}_{2} \times \mathbb{Z}_{2}$ atau $R$ merupakan ring lokal dengan char $R=$ patau $p^{2}$, dengan $|\Gamma(R)|=p^{n}-1$ untuk bilangan prima $p$ dan bilangan bulat $n \geq 1$. Jika $R \cong \mathbb{Z}_{p}$ maka $\Gamma(R)$ merupakan graf kosong karena tidak terdapat pembagi-nol pada graf $\Gamma(R)$, sehingga untuk tercapainya menjadi sebuah graf pembagi-nol lengkap maka haruslah $R \cong \mathbb{Z}_{p^{2}}$.

Contoh5:

Graf pembagi-nol lengkap dari $R \cong \mathbb{Z}_{3^{2}}$

$\mathbb{Z}_{3^{2}}=\mathbb{Z}_{9}$

$$
=\{0,1,2,3,4,5,6,7,8\} .
$$

Maka pembagi-nol dari $\mathbb{Z}_{9}$ adalah:

$3.3=9 \bmod 9=0$

$3.6=18 \bmod 9=0$

Sehingga, diperoleh:

$Z(R)=\{3,6\}$.

Bentuk graf $\Gamma(R)$ dengan $R \cong \mathbb{Z}_{9}$ dapat dilihat pada Gambar 5 berikut:

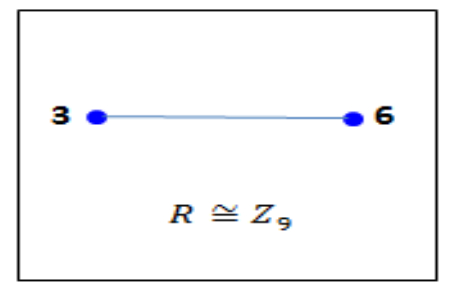

Gambar.5: Graf pembagi-nol lengkap $K_{2}$

Berdasarkan Gambar5, terlihat bahwa pola dari graf $\Gamma(R)$ lengkap dengan $R \cong \mathbb{Z}_{9}$ adalah $K_{(3-1)}=K_{2}$ dengan $|\Gamma(R)|=3-1=2$. Sehingga, untuk graf pembagi-nol bintang yang lain didapatkan:

Tabel.2:Pola Graf Pembagi-nol Lengkap

\begin{tabular}{cccc}
\hline No & Bentuk Ring & $\begin{array}{c}\text { Derajat Graf } \\
\Gamma(R)\end{array}$ & Pola Graf $\Gamma(R)$ \\
\hline 1 & $\mathbb{Z}_{2} \times \mathbb{Z}_{2}$ & 2 & $K_{2}$. \\
\hline 2 & $\mathbb{Z}_{2^{2}} \cong \mathbb{Z}_{4}$ & $2-1=1$ & $K_{2-1}=K_{1}$. \\
\hline 3 & $\mathbb{Z}_{3^{2}} \cong \mathbb{Z}_{9}$ & $3-1=2$ & $K_{3-1}=K_{2}$. \\
\hline 4 & $\mathbb{Z}_{5^{2}} \cong \mathbb{Z}_{25}$ & $5-1=4$ & $K_{5-1}=K_{4}$. \\
\hline 5 & $\mathbb{Z}_{7^{2}} \cong \mathbb{Z}_{49}$ & $7-1=6$ & $K_{7-1}=K_{6}$. \\
\hline
\end{tabular}

\section{Graf pembagi-nol bipartit lengkap}

Berdasarkan Akibat 2.2, graf pembagi-nol bipartit lengkap akan terbentuk jika $R \cong \mathbb{Z}_{m} \times \mathbb{Z}_{n}$, dengan $m, n \in P$, dimana $P$ adalah himpunan bilangan prima.

Contoh6:

Graf pembagi-nol bipartit lengkap dari $R \cong \mathbb{Z}_{3} \times \mathbb{Z}_{3}$ $\mathbb{Z}_{3} \times \mathbb{Z}_{3}=\{0,1,2\} \times\{0,1,2\}$

$$
\begin{aligned}
= & \{(0,0),(0,1),(0,2),(1,0),(1,1),(1,2),(2,0), \\
& (2,1),(2,2)\}
\end{aligned}
$$

Maka, pembagi-nol dari $R \cong \mathbb{Z}_{3} \times \mathbb{Z}_{3}$ :

$(0,1) \cdot(1,0)=0$

$(0,1) \cdot(2,0)=0$

$(0,2) \cdot(1,0)=0$

$(0,2) \cdot(2,0)=0$

Sehingga, diperoleh:

$Z(R)=\{(0,0),(0,1),(0,2),(1,0),(2,0)\}$.

Bentuk graf $\Gamma(R)$ dengan $R \cong \mathbb{Z}_{3} \times \mathbb{Z}_{3}$ dapat dilihat pada Gambar6 berikut :

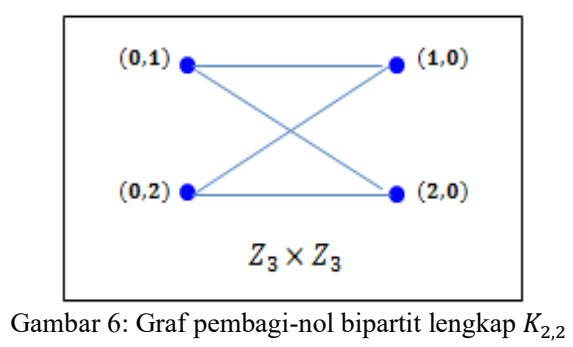

Berdasarkan gambar 6 , terlihat bahwa pola dari graf 
$\Gamma(R)$ bipartit lengkap dengan $R \cong \mathbb{Z}_{3} \times \mathbb{Z}_{3}$ adalah $K_{(3-1),(3-1)}=K_{2,2}$ dengan $|\Gamma(R)|=4$.

Tabel.3:Pola graf pembagi-nol bipartitlengkap

\begin{tabular}{cccc}
\hline No & $\begin{array}{c}\text { Bentuk } \\
\text { Ring }\end{array}$ & $\begin{array}{c}\text { Derajat Graf } \\
\Gamma(R)\end{array}$ & Pola Graf $\Gamma(R)$ \\
\hline 1 & $\mathbb{Z}_{3} \times \mathbb{Z}_{3}$ & $3+3-2=4$ & $K_{(3-1),(3-1)}=K_{2,2}$ \\
\hline 2 & $\mathbb{Z}_{3} \times \mathbb{Z}_{5}$ & $3+5-2=6$ & $K_{(3-1),(5-1)}=K_{2,4}$ \\
\hline 3 & $\mathbb{Z}_{5} \times \mathbb{Z}_{5}$ & $5+5-2=8$ & $K_{(5-1),(5-1)}=K_{4,4}$ \\
\hline 4 & $\mathbb{Z}_{5} \cong \mathbb{Z}_{7}$ & $5+7-2=10$ & $K_{(5-1),(7-1)}=K_{6}$. \\
\hline
\end{tabular}

Berdasarkan hasil dari representasi dari sampel graf pada Tabel 3, dapat dilihat bahwa pola dari sampel-sampel graf pembagi-nol bipartit lengkap di atas, membentuk sebuah pola umum, yaitu $K_{(m-1),(n-1)}$, dimana $m, n$ adalah elemen himpunan bilangan prima. Akibatnya, graf pembagi-nol bipartit lengkap dengan $R \cong \mathbb{Z}_{m} \times \mathbb{Z}_{n}$ dimana $m=n \quad$ memliki pola $K_{(m-1),(m-1)}$ dengan $|\Gamma(R)|=2 m-2$.

\subsection{Automorfismagraf pembagi-nol}

Automorfisma dari graf $\Gamma(R)$ merupakan suatu permutasi $\varphi$ dari himpunan $V(G)$ yaitu himpunan semua titik-titik dari $\Gamma(R)$, yang bersifat $(x, y) \in E(\Gamma(R))$ jika dan hanya jika $(\varphi(x), \varphi(y)) \in E(\Gamma(R))$, artinya bahwa automorfisma dari graf $\Gamma(R)$ merupakan semua pemetaan bijektif dari himpunan semua titik di $\Gamma(R)$ yang bersifat mengawetkan ketetanggan pada $\Gamma(R)$.

\section{Graf pembagi-nol bintang}

Contoh7:

Graf pembagi-nol bintang dengan pola $K_{1,2}$

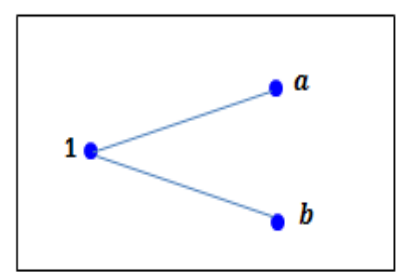

Gambar.7: Graf pembagi-nol bintang $K_{1,2}$

Graf pembagi-nol bintang $K_{1,2}$ memiliki 3 simpul $V\left(K_{1,2}\right)=\{1, a, b\}$, dimana simpul 1 berderajat 2 dan simpul $a$ dan $b$ masing-masing berderajat 1 , sehingga automorfisma pada graf pembagi-nol bintang $K_{1,2}$ atau $\varphi: K_{1,2} \rightarrow K_{1,2}$ adalah sebagai berikut:

Tabel.4:Automorfisma graf pembagi-nol bintang $K_{1,2}$

\begin{tabular}{|c|c|c|c|}
\hline No & $\begin{array}{c}\text { Automorfisma Graf } \\
\Gamma(R)\end{array}$ & No & $\begin{array}{c}\text { Automorfisma Graf } \\
\Gamma(R)\end{array}$ \\
\hline \multirow[t]{6}{*}{1} & $\varphi_{1}(1)=1$ & 2 & $\varphi_{2}(1)=1$ \\
\hline & $\varphi_{1}(a)=a$ & & $\varphi_{2}(a)=b$ \\
\hline & $\varphi_{1}(b)=b$ & & $\varphi_{2}(b)=a$ \\
\hline & Atau dapat ditulis: & & Atau dapat ditulis: \\
\hline & $\varphi_{1}=\left(\begin{array}{lll}1 & a & b \\
1 & a & b\end{array}\right)$ & & $\varphi_{2}=\left(\begin{array}{lll}1 & a & b \\
1 & b & a\end{array}\right)$ \\
\hline & $=(1)(a)(b)$ & & $=(1)(a b)$ \\
\hline
\end{tabular}

Berdasarkan hasil dari pemetaan $\varphi: K_{1,2} \rightarrow K_{1,2}$ di atas, diketahui bahwa jumlah automorfisma dari graf pembaginol bintang $K_{1,2}$ adalah 2. Untuk Graf Pembagi-nol lainnya, dilakukann hal yang sama maka didapatkan hasil yang dipaparkan pada tabel berikut.

Tabel.5:Automorfisma graf pembagi-nol bintang $K_{1,(p-1)}$

\begin{tabular}{cccc}
\hline No & $\begin{array}{c}\text { Ring dari } \\
\text { Graf } \Gamma(R)\end{array}$ & $\begin{array}{c}\text { Pola Graf } \\
\Gamma(R)\end{array}$ & $\begin{array}{c}\text { Banyak } \\
\text { Automorfisma }\end{array}$ \\
\hline 1 & $\mathbb{Z}_{2} \times \mathbb{Z}_{3}$ & $K_{1,2}$ & $2=2 !$ \\
\hline 2 & $\mathbb{Z}_{2} \times \mathbb{Z}_{5}$ & $K_{1,4}$ & $24=4 !$ \\
\hline 3 & $\mathbb{Z}_{2} \times \mathbb{Z}_{7}$ & $K_{1,7}$ & $720=6 !$ \\
\hline
\end{tabular}

Berdasarkan Tabel 5, dapat dilihat bahwa pola automorfisma dari sampel-sampel graf pembagi-nol bintang di atas, mengikuti pola automorfisma dari graf bintang pada umumnya, yaitu $n$ !untuk setiap $n$ elemen bilangan asli. Oleh karena itu, dapat disimpulkan bahwa graf pembagi-nol bintang dengan pola $K_{1,(p-1)}$, untuk setiap $p$ anggota himpunan bilangan prima memiliki automorfisma sebanyak $(p-1)$ !.

\section{Graf pembagi-nol bintang}

Contoh 8:

Graf pembagi-nol lengkap dengan pola $K_{2}$ 


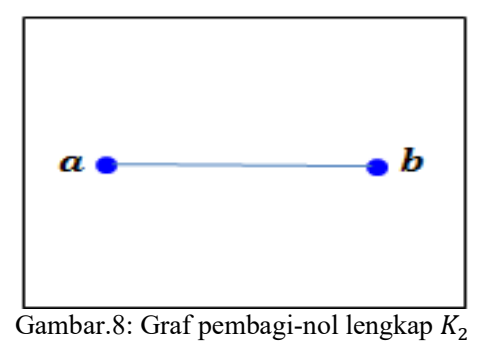

Graf pembagi-nol bintang $K_{2}$ memiliki 2 simpul $V\left(K_{2}\right)=\{a, b\}$, dimana simpul $a$ dan $b$ masing-masing berderajat 1 ,sehingga automorfisma pada graf pembagi-nol bintang $K_{2}$ atau $\varphi: K_{2} \rightarrow K_{2}$ adalah sebagai berikut:

Tabel.6:Automorfisma graf pembagi-nol lengkap $K_{2}$

\begin{tabular}{llll}
\hline No & $\begin{array}{c}\text { Automorfisma Graf } \\
\Gamma(R)\end{array}$ & No & $\begin{array}{c}\text { Automorfisma Graf } \\
\Gamma(R)\end{array}$ \\
\hline 1 & $\varphi_{1}(a)=a$ & 2 & $\varphi_{2}(a)=b$ \\
& $\varphi_{1}(b)=b$ & & $\varphi_{2}(b)=a$
\end{tabular}

Atau dapat ditulis:

Atau dapat ditulis:

$$
\begin{aligned}
\varphi_{1} & =\left(\begin{array}{ll}
a & b \\
a & b
\end{array}\right) & \varphi_{2} & =\left(\begin{array}{ll}
a & b \\
b & a
\end{array}\right) \\
& =(1)(a) & & =(a b)
\end{aligned}
$$

Berdasarkan hasil dari pemetaan $\varphi: K_{2} \rightarrow K_{2}$ di atas, diketahui bahwa jumlah automorfisma dari graf pembaginol lengkap $K_{2}$ adalah 2.Untuk Graf Pembagi-nol lengkap lainnya, dilakukann hal yang sama maka didapatkanhasil yang dipaparkan pada tabel berikut.

Tabel.7:Automorfisma graf pembagi-nol lengkap $K_{p-1}$

\begin{tabular}{cccc}
\hline No & Ring dari Graf $\Gamma(R)$ & $\begin{array}{c}\text { Pola Graf } \\
\Gamma(R)\end{array}$ & $\begin{array}{c}\text { Banyak } \\
\text { Automorfisma }\end{array}$ \\
\hline 1 & $R \cong \mathbb{Z}_{2^{2}}$ & $K_{1}$ & $1=1 !$ \\
\hline 2 & $R \cong \mathbb{Z}_{2} \times \mathbb{Z}_{2}$ atau & $K_{2}$ & $2=2 !$ \\
$R \cong \mathbb{Z}_{3^{2}}$ & & \\
\hline 3 & $R \cong \mathbb{Z}_{5^{2}}$ & $K_{4}$ & $24=4 !$
\end{tabular}

Berdasarkan hasil dari urain automorfisma dari grafgraf pembagi-nol lengkap pada Tabel 7 , dapat dilihat bahwa pola automorfisma dari sampel-sampel graf pembagi-nol lengkap yang terbentuk, mengikuti pola automorfisma dari graf lengkap pada umumnya, yaitu $n !$, untuk setiap $n$ elemen himpunan bilangan asli. Oleh karena itu, dapat disimpulkan bahwa pola graf pembagi-nol lengkap dengan pola $K_{p-1}$, untuk setiap $p$ anggota himpunan bilangan prima, memiliki automorfisma sebanyak $(p-1)$ !.

\section{Graf pembagi-nol bipartit lengkap}

Contoh 9:

Graf pembagi-nol bipartit lengkap $K_{1,2}$

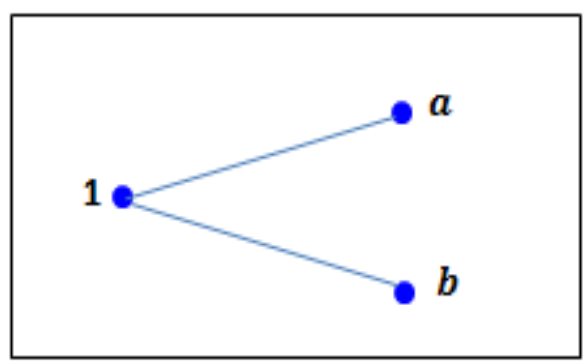

Gambar.9: Graf pembagi-nol bipartit lengkap $K_{1,2}$

Graf pembagi-nol bipartit lengkap $K_{1,2}$ memiliki 3 simpul $V\left(K_{1,2}\right)=\{1, a, b\}$, dimana simpul 1 berderajat 2 dan simpul $a$ dan $b$ masing-masing berderajat 1 , sehingga automorfisma pada graf pembagi-nol bipartit lengkap $K_{1,2}$ atau $\varphi: K_{1,2} \rightarrow K_{1,2}$ adalah sebagai berikut:

Tabel.8:Automorfisma graf pembagi-nol bipartit lengkap $K_{2}$

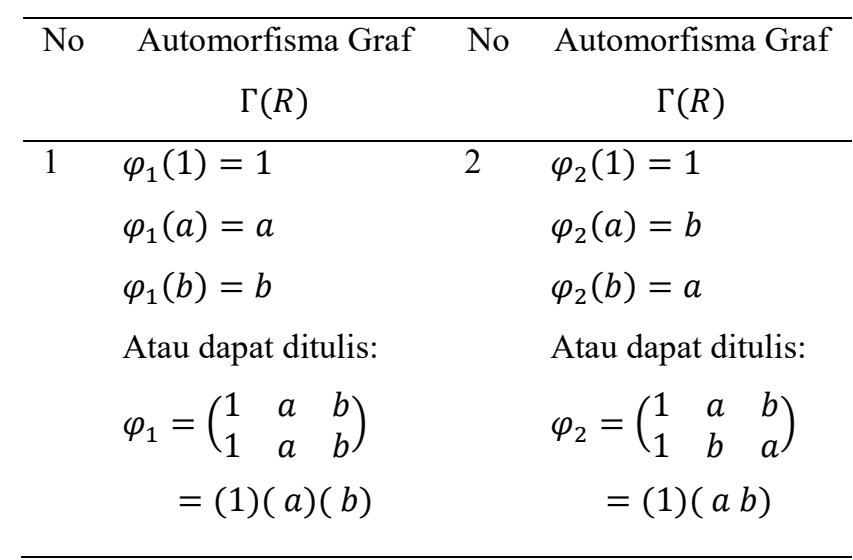

Berdasarkan hasil dari pemetaan $\varphi: K_{1,2} \rightarrow K_{1,2}$ di atas, diketahui bahwa jumlah automorfisma dari graf pembaginol bipartit lengkap $K_{1,2}$ adalah 2.Untuk Graf Pembagi-nol bipartit lengkap lainnya, dilakukann hal yang sama maka didapatkan

Tabel.9:Automorfisma graf pembagi-nol bipartit 
lengkap $K_{(p-1),(q-1)}$

\begin{tabular}{|c|c|c|c|}
\hline No & Ring dari Graf $\Gamma(R)$ & $\begin{array}{l}\text { Pola Graf } \\
\qquad \Gamma(R)\end{array}$ & $\begin{array}{c}\text { Banyak } \\
\text { Automorfisma }\end{array}$ \\
\hline 1 & $R \cong \mathbb{Z}_{2} \times \mathbb{Z}_{2}$ & $K_{1,1}$ & $\begin{array}{l}1 ! * 1 !+1 ! \\
* 1 !=2\end{array}$ \\
\hline 2 & $R \cong \mathbb{Z}_{3} \times \mathbb{Z}_{3}$ & $K_{2,2}$ & $\begin{array}{l}2 ! * 2 !+2 ! \\
* 2 !=8\end{array}$ \\
\hline 3 & $R \cong \mathbb{Z}_{2} \times \mathbb{Z}_{3}$ & $K_{1,2}$ & $1 ! * 2 !=2$ \\
\hline 4 & $R \cong \mathbb{Z}_{3} \times \mathbb{Z}_{5}$ & $K_{2,4}$ & $2 ! * 4 !=48$ \\
\hline
\end{tabular}

Berdasarkan hasil uraian automorfisma dari sampelsampel graf pembagi-nol bipartit lengkap pada Tabel 9, dapat dilihat bahwa pola automorfisma dari sampel-sampel graf pembagi-nol bipartit lengkap yang terbentuk mengikuti pola automorfisma dari graf bipartit lengkap pada umumnya, yaitu $m ! * n !$, untuk setiap $m, n$ elemen himpunan bilangan asli . Oleh karena itu, dapat disimpulkan bahwa graf pembagi-nol bipartit lengkap dengan pola $K_{(p-1),(q-1)}$, untuk $p \neq q$ memiliki pola automorfisma $(p-1)$ ! $*(q-1)$ !. Sedangkan, untuk graf pembagi-nol bipartit lengkap dengan pola $K_{(p-1),(q-1)}$, untuk $p=q$ memiliki pola $2[(p-1) ! *(p-1) !]$.

\section{UCAPAN TERIMA KASIH}

Dalam kesempatan ini penulis ingin menyampaikan ucapan terima kasih yang tak terhingga kepada:

1. Allah SWT yang selalu memberikan rahmat dan hidayah-Nya.

2. Kedua Orang tua beserta saudara-saudara tercinta, untuk segala yang telah diperjuankan selama ini.

3. Bapak/ibu dosen khususnya para dosen pembimbing atas kesediaannya meluangkan waktu untuk memberikan bimbingan, arahan, dan bantuan tak terhingga kepada penulis, sehingga penelitian ini dapat terselesaikan.

4. Sahabatku dan teman-teman Matematika angkatan 2011 atas semangat dan dukungannya.

\section{DAFTAR PUSTAKA}

Anderson, D. D. dan Philip S. Livingstone, 1999, The Zero-Divisor Graph of a commutative Ring, Jurnal of Algebra, 211, Mathematic Departement, The University of Tenessee, Knoxvile.

Arifin, A., 2000, Aljabar, ITB Bandung press, Bandung.

Munir, R., 2009, Matematika Diskrit Edisi Ketiga, Informatika, Bandung.

Suryoto, 2011, Automorfisma Graph, Jurnal Matematika dan Komputer, 4 No. 3, Jurusan Matematika FMIPA UNDIP, Semarang.

Wicaksono, S. A. dan Soleha, 2013, Kajian Sifat-Sifat Graf Pembagi-nol dari Ring Komutatif dengan Elemen Satuan, Jurnal Sains dan Seni Pomits, Vol.2 No.1, Jurusan Matematika FMIPA ITS, Surabaya. 